\title{
Penciptaan Permainan Digital Edukatif Berbasis Wawasan Budaya Dan Pendidikan Karakter
}

\author{
Samuel Gandang Gunanto \\ Program Studi Animasi, Fakultas Seni Media Rekam, \\ Institut Seni Indonesia Yogyakarta \\ e-mail: gandang@isi.ac.id
}

\begin{abstract}
Abstrak
Fenomena permainan digital atau yang lebih dikenal dengan istilah game berkembang pesat dalam dua dekade terakhir ini. Perkembangan ini mendapat banyak sorotan dari berbagai pihak, ada yang melihat dari sisi negatif ada pula yang melihat dari sisi positif. Kurangnya pengembang game yang ber-genre edukasi mengakibatkan sedikitnya variasi pengembangan edukasi yang disajikan, saat ini masih seputar tentang pendidikan dan pembelajaran mengenal hewan, mengenal profesi, mengenal benda, belajar berhitung, belajar membaca ataupun konten-konten lainnya yang dahulu berkembang dalam wujud karya $\mathrm{CD}$ multimedia interaktif. Bentuk-bentuk ini masih memiliki kesan sebagai pembelajaran sistem tutor dan kurang mempertimbangkan sisi imersif atau kemenarikan dalam dunia game.

Pada penelitian dan penciptaan karya ini dikembangkan aspek imersif dari sebuah game yang berwujud pembelajaran pendidikan karakter, secara khusus tentang "sikap kepedulian terhadap kebersihan lingkungan". Tema pendidikan karakter dalam wujud karya game sangat menarik untuk diangkat dikarenakan penanaman kepedulian terasa lebih mengena diajarkan dalam bentuk sistem partisipasi dalam peran, sehingga pengguna secara langsung akan mengalaminya dan seolah-olah berperan selaku tokoh utama game. Sebagai perwujudannya, penciptaan berpusat pada budaya dan kearifan lokal dengan mengangkat tokoh punakawan sebagai landasan penokohan karakter dan desain antarmuka game.
\end{abstract}

Kata kunci: game edukasi, punakawan, karakter, peduli lingkungan

\section{Abstrak}

The phenomenon of digital games, or better known by the term game, developed rapidly in the last two decades. This process received a lot of attention from various parties, there is the view of the negative side there is also viewed from the positive side. Lack of game developers on educational game resulted in the least variations of development, it is still around about education and learning about animals, get to know the profession, recognizes objects, learn to count, learn to read or other contents were first developed in the form of interactive multimedia. These forms still have the impression of being a tutor system of learning and less immersive of the gaming world.

The research and creation developed an immersive aspect of a game that is tangible for teaching a moral education, specifically about "caring attitude towards environmental hygiene". Moral education themes are very interesting due to the participation in the role of the game system, so users will directly experience it and 


\section{Samuel Gandang Gunanto}

Penciptaan Permainan Digital Edukatif Berbasis Wawasan Nusantara dan Pendidikan

Karakter

serving as the main character. As a manifestation, the creation is centered on culture and local wisdom to promote Punakawan's character as the base characterizations and game interface design.

Keywords: educational games, moral education, caring

\section{Pendahuluan}

Fenomena permainan digital atau yang lebih dikenal dengan istilah game berkembang pesat dalam dua dekade terakhir ini. Perkembangan ini mendapat banyak sorotan dari berbagai pihak, ada yang melihat dari sisi negatif ada pula yang melihat dari sisi positif. Sorotan yang paling gencar di tanah air ini adalah saat Komisi Perlindungan Anak Indonesia (KPAI) memiliki wacana untuk memblokir sejumlah game terkenal di Indonesia karena dianggap memiliki konten yang tidak sesuai untuk anak-anak. Tindakan ini oleh KPAI dianggap sebagai salah satu cara untuk membantu orangtua dalam mengontrol jenis game yang dimainkan oleh anak.

Pengaturan masalah rating pengguna game sudah diatur oleh lembagalembaga internasional di dunia. Lembaga rating game di Amerika Serikat dinamakan Entertainment Software Rating Board (ESRB), di Jepang dinamakan Computer Entertainment Rating Organization (CERO), dan di Eropa dinamakan Pan European Game Information (PEGI). Masing-masing lembaga rating memiliki deskripsi untuk menjelaskan konten game seperti tingkat kekerasan adegan dan saran umur pengguna game tersebut. Namun hal ini kurang tersosialisasikan dan kurang mendapatkan perhatian dari para orang tua ataupun pengguna game itu sendiri karena mereka masih berasumsi jika permainan yang dalam kategori game adalah permainan anak-anak saja.

Kurangnya pengembang game yang mampu menghasilkan tipe game edukasi di Indonesia juga secara tidak langsung menjadi salah satu alasan mengapa banyak pengguna game yang memilih permainan game dengan tipe kekerasan. Banyaknya ketersediaan game ber-genre aksi dan kemudahannya dalam mengakses game tersebut mendorong banyak pengembang game untuk terjun menghasilkan karya yang serupa dibandingkan harus terjun di kategori 